\title{
The Comparison of the Intuitive Mathematic Skills of Preschool Children Who Take Education According to Ministry of National Education Preschool Education Program and Montessori Approach
}

\author{
Yildiz Guven \\ Maltepe University, Faculty of Education, Preschool Teachers Training Program \\ E-mail: yildizgvn@gmail.com \\ Seray Durkaya \\ E-mail: seray.asantogrul@gmail.com
}

\begin{abstract}
This study analyzed intuitive mathematics abilities of preschool children and to ascertain whether there was a difference between children who were educated according to the Ministry of National Education (MoNE) preschool education program and the Montessori approach. It was also examined whether the intuitive mathematics abilities of the children who were educated according to the MoNE program and Montessori approach showed a significant difference according to variables of gender, duration of pre-school education, and educational levels of parents. The study sample of the study consisted of 121 children (56 girls, 65 boys) aged between 60-72 months. The data was collected via "Personal Information Form" and "Intuitive Mathematics Ability Scale" developed by Güven (2001). Intuitive mathematical abilities of children who were educated according to the Montessori program were more developed compared to those of children educated according to MoNE program. There was no significant difference in intuitive mathematical abilities according to duration of preschool education, education levels of parents. As a result of the study, a significant difference was observed in the intuitive math abilities of the children trained according to the MoNE program in favor of the girls, whereas no significant difference was observed trained according to the Montessori approach. The results are discussed in light of the relevant literature.
\end{abstract}

Keywords: Intuitive mathematics ability, National Preschool Education Program, Montessori approach

DOI: $10.7176 / J S T R / 6-06-12$

\section{MEB Okul Öncesi Eğitim Programına ve Montessori Yaklaşımına Göre Eğitim Alan Okul Öncesi Dönem Çocukların Sezgisel Matematik Yeteneklerinin Karşılaştırılması}

Bu çalışma, Seray Durkaya tarafından yazılan, Marmara Üniversitesi Eğitim Bilimleri Enstitüsü tarafından kabul edilen, YÖK'te 567612 sayı numarasıla kayıtlı olan yüksek lisans tezinden türetilmiştir.

Özet

$\mathrm{Bu}$ araştırmada MEB Okul Öncesi Eğitim Programına ve Montessori eğitim yaklaşımına göre eğitim alan çocukların sezgisel matematik yeteneklerinin karşılaştırılması amaçlanmıştır. Araştırmanın amacı doğrultusunda MEB programına ve Montessori yaklaşımına göre eğitim alan çocukların sezgisel matematik yeteneklerinin cinsiyet, okul öncesi eğitime devam süresi, anne ve babanın öğrenim durumu değişkenlerine $\mathbf{1 6 7} \mid \mathrm{P}$ a g e

WWW.iiste.org 
göre anlamlı bir farklılık gösterip göstermediği de incelenmiştir. İstanbul'da MEB Programı'na ve Montessori eğitim yaklaşımına göre eğitim veren okul öncesi kurumlara devam eden çocuklardan toplam 121 çocuk (56 kız-65 erkek) araştırmanın çalışma grubunu oluşturmuştur. Çalışmanın verileri Güven (2001) tarafından geliştirilmiş olan "Sezgisel Matematik Yeteneği Testi” ile toplanmıştır. Yapılan analizler sonucunda MEB programına ve Montessori yaklaşımına göre eğitim alan çocukların sezgisel matematik yetenekleri arasında Montessori yaklaşımına göre eğitim alan çocuklar lehine anlamlı bir farklılık bulunmuştur. Çocukların okul öncesi eğitime devam etme süreleri ve anne-baba öğrenim durumlarına göre sezgisel matematik yetenekleri farklılık göstermezken, MEB programına göre eğitim alan çocukların sezgisel matematik yeteneklerinde kız çocuklarının lehine anlamlı bir farklılık bulunmuştur. Elde edilen bulgular ilgili literatür çerçevesinde tartışılmıştır.

Anahtar Kelimeler: Sezgisel matematik yeteneği, MEB Okul Öncesi Eğitim Programı, Montessori yaklaşımı

\section{Giriş}

Erken çocukluk döneminde çocuğun nesnelerle olan etkileşimi sonucunda matematikle ilgili ilk tecrübeler genellikle informal yolla kazanılır, sonrasında okul hayatının başlaması ile formal yolla kazanılmaya devam eder (Güven, 1997). Çocuk günlük yaşamında matematik ile ilgili birçok temel kavramla bu dönemde karşılaşmakta ve öğrenmeye başlamaktadırlar (Bağc1 \& İvrendi, 2016; Çelik \& Kandır, 2011; Erdoğan, 2006). Bu dönemde çocuk formal olmayan matematik becerilerini aile ve sosyal çevresi ile kurduğu etkileşimle kazanır (Avci, 2015; Çelik \& Kandır, 2011). Araştırmalar çocukların ilkokul dönemindeki matematik performanslarının okul öncesi eğitim alma durumlarından olumlu yönde etkilendiğini göstermektedir (Jordan \& ark., 2009; Lopez \& ark., 2007; Mazzocco \& Thompson, 2005).

Sezgi, Webster's NewWorld Dictionary'de (1970) "Bir problemin tümünün dolaylı olarak çok dikkatle incelenmeden algılanması" olarak açıklanmıştır. Yıldırım (1996) ise sezgiyi "Bilgiye gözlem ya da çıkarım yoluyla değil, doğrudan ulaşma yetisi (iç-kavrayış)” olarak tanımlamıştır. Baroody (1987) okul öncesi dönemde kazanılan matematik becerilerinin sezgilerin işlenmesi yoluyla kazanıldığını ifade etmektedir. Sezgisel düşünme, tüm insanların neredeyse her yaşta günlük hayatında kullandığı bir düşünme tarzıdır ve yaşantımız için gerekli ve önemlidir. Çocukların formal eğitimde kazanacakları yazılı sembollere dayanan sistematik matematiğin zeminini bu deneyimler oluşturacaktır. Araştırmalara göre sezgisel düşünmenin birey için matematiksel problemlerdeki başarıyı artırma, problem çözme sürecini güçlendirme, bağlantıları hızlı ve net kavramaya yardım etme gibi birçok olumlu etkisi vardır (Güven, 2004). Bruner'e (1983) göre eğitimciler çocukları sezgilerini kullanma konusunda cesaretlendirmelidirler. Okul öncesi dönem bireylerin bu yönünü güçlendirmek için en önemli dönemdir (Canoğlu, 2007). Piaget (1984) bilişsel gelişimi dört gelişimsel döneme ayırır ve okul öncesi döneme tekabül eden gelişimsel dönemi ise işlem öncesi dönem olarak adlandırır. İşlem öncesi dönem iki alt evreye ayrılır. Piaget 4-6 yaş aralığını kaplayan evreye sezgisel düşünce evresi adını verir (Güven, 2005; Küçükkaragöz, 2011). Bu evrede çocuk mantıksal çıkarımlar, güçlü akıl yürütmeler yapamadığı için sezgileri aracılığıyla zaman, mekân, miktar, sayılar gibi kavramları anlamaya çalışırlar. Bu dönemde problemlerini ön-mantıksal süreçlerle çözmek için çabalarlar ve sezgilerini kendilerine bildik gelen, tanıdıkları durumlarla ilgili olarak kullanırlar (Güven, 2007). Analitik düşüncede deneye ve istatistiksel analizlere dayalı belli ve değişmez basamaklar varken sezgisel düşüncede belirli basamaklar yoktur. Sezgisel düşünce ile elde edilen bulgunun doğruluğu veya yanlışlı̆̆ı daha sonra kullanılacak bilimsel yöntemlerle ortaya çıkacaktır (Ceylan, 2016). Sezgisel düşünme sürecindeki tecrübeler matematiksel problemlerdeki başarının artmasına, problem çözme aşamasının güçlenmesine, bağlantıların hızlı ve açık algılanmasına zemin oluşturur (Dixon \& Moore, 1996).

Türkiye'de uygulanan MEB Okul Öncesi Eğitim Programı farklı yaklaşım ve modelleri baz alarak oluşturulmuş olup model olarak eklektiktir. Program farklı öğrenme yaklaşım ve modellerindeki (Waldorf, Montessori, High Scope, Reggio Emilia gibi) çocuk merkezli uygulamaların bir sentezi olacak şekilde hazırlanmıştır. MEB Okul Öncesi Eğitim Programı'na göre, çocuğun zihinsel gelişimine katkı sağlamak, çocuklarda matematiğe yönelik pozitif bir bakış açısı oluşturmak, çocukların var olan kavramsal yapılarıyla edindikleri yeni bilgiler arasında bağ kurmalarına yardımcı olmak, matematiksel kavramların ne amaçla ve ne şekilde kullanıldığını anlamalarına yardımcı olmak matematik eğitiminin amacıdır (MEB, 2013; Toran, 2015). Günümüzde birçok okulöncesi eğitim kurumunda birçok eğitim yaklaşımı çocukların bütünsel gelişimine katkı sağlayacak elverişli koşulları oluşturmak maksadıyla uygulanmaktadır. Çocuğun gelişimi ve eğitimi için en yüksek yarara ulaşmak bu yaklaşımların ortak amacıdır (Köksal Aksoy \& Aslan, 2006). $\mathrm{Bu}$ okullar içerisinde Montessori eğitim yaklaşımını uygulayan okullar da bulunmaktadır.

$\mathbf{1 6 8} \mid \mathrm{P}$ a g e

www.iiste.org 
Erken çocukluk döneminde bireyin eğitimine yönelik çalışmaları ve ortaya çıkardığı yöntemi ile dünyaca ünlü eğitimcilerden birisi Maria Montessori'dir (Çakıroğlu Wilbrandt, 2017; Korkmaz, 2005; Oktay, 1987; Topbaş, 2017). Okul öncesi dönemde matematiğin öğrenilmesi amaciyla somuttan soyuta doğru bir yol izleyen Montessori, bu dönemde çocuğun temel matematiksel bilgileri kazanması için alıştırmalar yapması gerektiğini söyler. Soyut kavramları somutlaştırması Montessori matematik materyallerinin en temel özelliğidir. Temel matematik kavramların kazanılması Montessori matematik materyalleri sayesinde daha da anlaşılır hale gelmektedir (Durakoğlu, 2010). Bu yaklaşım bağlamında bakıldığında Montessori eğitimi alan çocuklar başarı kavramı odaklı değil, süreci tahlil ederek, keşfederek, kendi tercihlerini yaparak ve zihnini yönlendirerek eğitime dâhil olurlar (Yiğit, 2008). Ona göre küçük çocuklar bilgiyi deneyerek adeta emmeye çalışırlar (“emici zihin”) (Montessori, 1936/1997; Yıldız, 2018). Montessori çocukların hareket etmelerine, dokunmalarına ve keşfetmelerine olanak sağlandığı ölçüde öğrenmenin yaparak, yaşayarak öğrenileceğini savunur (Aydın, 2015). Montessori programı geleneksel eğitim programlarındaki gibi etkinlik, dinlenme ya da oyun zamanlarına ayrılmamıştır (Cossentino, 2006; Sobe, 2004). Materyaller yoluyla çocuk kendi kendini eğitir ve hatalarını görüp düzeltme firsatı bulur (Temel \& Toran, 2013).

Araştırmacılar tarafından Montessori yaklaşımı ile MEB Okul Öncesi Eğitim Programı arasında çeşitli karşılaştırmalar yapılmıştır. Bu yaklaşımlar incelendiğinde bazı benzerlikler ve farklılıklar görülmüştür (Toran, 2015). Montessori materyalleri özel tasarlanmış materyaller olup, materyalin tek bir kullanım şekline sahiptir ve hata kontrolü vardır. Ulusal programın uygulandığı Milli Eğitim Bakanlığına bağlı okullarda ise sınıf içerisindeki materyallerin tek doğru kullanım şekli yoktur. Birden fazla kullanım şekline uygundur. Montessori yaklaşımında öğrenmede bireysel farklılıklar esastır ve öğretmen yönlendirmesi daha azdır. Milli Eğitim Bakanlığına bağlı okullarda ise daha çok öğretmenlerin planlarına uygun olarak tasarlanmış bir ortamda çalışılır ve öğretmenin yönlendirmesi ile yapılan grup etkinlikleri daha çoktur. Etkinlik esnasında hata yapan çocuğa dönüt verilerek düzeltilir. Montessori eğitim ortamlarında ise çocuk öğretmen müdahalesinin daha az olduğu bir ortamda çalışır, hatalar çocuğa dönüt verilerek düzeltilmez. Çocuk hatasını kendisi bulur (Keçecioğlu, 2015; Oğuz \& Köksal Akyol, 2006). Çocuk merkezli olan her iki programda da yaparak-yaşayarak öğrenme esastır.

Yurtiçi ve yurtdışı araştırmalar incelendiğinde ulusal program ile Montessori yaklaşımının karşılaştırıldığ pek çok araştırmaya rastlanmış (Aydoğan Akuysal, 2007; Dohrmann, 2003; Ervin, 2010; Faryadi, 2017; Fitzpatrick vd., 2014; Gross, 1970; Harris, 2007; Hobbs 2008; Kırlar, 2006; Laski, Vasilyeva, Schiffman \& Ermakova, 2016; Lillard \& ElseQuest, 2006; Lillard \& Heise, 2016; Lopata, Wallace, \& Finn, 2005; Mallett \& Schroeder, 2015; McIntosh, 2015; Öngören, 2008; Peng \& Md-Yunus, 2014; Toran, 2011; Toran \& Temel, 2014; Yiğit, 2008; White, Yussen \& Docherty, 1976) ve araştırmaların farklı sonuçlar verdiği görülmüştür. Alanyazında rastlanmadığı için Türkiye'de okul öncesi eğitime devam eden çocukların sezgisel matematik yeteneklerinin eğitim gördükleri program türüne göre karşılaştırılmasına ihtiyaç duyulmuştur.

\subsection{Amaç}

MEB okul öncesi eğitim programı ve Montessori yaklaşımına göre eğitim alan 60-72 aylık çocukların sezgisel matematik yeteneklerinin karşılaştırılması bu araştırmanın temel amacını oluşturmuştur. Bu amaç doğrultusunda çocukların sezgisel matematik yeteneklerinin; cinsiyetlerine, yaşlarına, okul öncesi eğitime devam etme sürelerine, anne ve baba öğrenim durumlarına göre farklılaşma durumları da incelenecektir.

\section{Yöntem}

\subsection{Araștırmanın Modeli}

$\mathrm{Bu}$ çalışmada MEB programı ve Montessori yaklaşımına göre eğitim alan 60-72 aylık çocukların sezgisel matematik yeteneklerinin karşılaştırılması amacıyla İlişkisel Tarama Model'inin bir çeşidi olan karşılaştırma türü ilişkisel tarama modeli kullanılmıştır. İlişkisel tarama modelleri, iki ve daha fazla değişken arasında birlikte değişimin varlığını ve/veya derecesini belirlemeyi amaçlayan araştırma modelleridir (Karasar, 2016).

\section{2. Çalışma Grubu}

Araştırmanın çalışma grubunu; İstanbul'daki MEB programına (61 çocuk, ay ortalaması 66,13) ve Montessori yaklaşımına (60 çocuk, ay ortalaması 64,95) göre eğitim alan 60-72 ay aralığındaki 121 çocuk oluşturmuştur. MEB programına tabi olan çocukların \%47,54'ü kı, \%52,46's1 erkek, Montessori yaklaşımına tabi olan çocukların ise $\% 45$ 'i kız, $\% 55$ 'i erkektir. 


\subsection{Veri Toplama Araçları}

\subsubsection{Kișisel Bilgi Formu}

Kişisel Bilgi Formu, çalışma grubundaki çocukların yaş, cinsiyet, okul öncesi eğitime devam süresi, annebabalarının öğrenim düzeyi sorularına cevap aramaktadır. Kişisel Bilgi Formları öğrenci velileri ve okul yönetimleri tarafindan doldurulmuştur.

\subsubsection{Sezgisel Matematik Yeteneği Testi}

Sezgisel Matematik Yeteneği Testi (SMYT) Güven (2001) tarafından 4-6 yaş çocukların sezgisel yeteneklerini matematiksel alanlarda (miktar, büyüklük, uzunluk, ağırlık ve sayısal büyüklük) ölçmek amacıyla geliştirilmiştir. Bireysel bir test olup 35 sorudan oluşmaktadır. Uygulama süresi 15 dakika olan testte sorular resim veya semboller şeklinde düzenlenmiştir. Testin bazı maddeleri kolay temin edilebilen somut nesnelerle (plastik bardak, pamuk, kurşun kalem, çay markası-para gibi yuvarlak nesneler) uygulanmaktadır. Testin kapsamına giren matematiksel alanlar ve soru sayıları ise; miktar (azlık-çokluk) (10 soru), büyüklük (hacim) (8 soru), uzunluk ( 8 soru), ağırlık ( 8 soru), sayısal büyüklük (1 soru) olarak tespit edilmiştir. Çocukların yaşlarının küçük olması nedeniyle sorular daha çok hikayeleştirilerek sunulmaktadır. Her sorunun cevaplama süresi 5 saniye sınırlıdır. Cevap formunda doğru yanıtlar artı, yanlış yanıtlar eksi olarak işaretlenmekte ve çocuğun aldığı test puan1 35 sorudan aldığı doğru yanıtların toplamından oluşmaktadır. Testin madde analizi çalışmaları (madde toplam, madde kalan ve ayırt edicilik) neticesinde 38 sorudan oluşan test 35 soruya indirgenmiştir. Testin yap1 geçerliğini tespit amac1yla bir ilköğretim okuluna devem eden 32 anasınıfı çocuğuna Erken Matematik Yeteneği Testi-2 ile Sezgisel Matematik Yeteneği Testi birlikte uygulanmış ve uygulama sonucu elde edilen Pearson Çarpım Momentler Korelasyon Katsayısı .84 olarak, iç tutarlılık katsayısı (Cronbach alfa) ise .73 olarak bulunmuştur. Test-tekrar test uygulaması sonucunda elde edilen korelasyon katsayısı ise $.76^{\prime}$ dır. Yaş grupları dikkate alındığında ise 4, 5 ve 6 yaşlarda elde edilen SMYT puan ortalamaları, standart sapmaları ve Scheffe testi bulguları testin yaş değişkene bağlı olarak değiştiğini göstermektedir. Testin kriter geçerliğini saptamak amacıyla öğretmen görüşlerine başvurulmuştur. Matematik yeteneği öğretmenleri tarafından üstün görülen çocuklarla, öğretmenleri tarafından orta düzeyde görülen çocuklar arasında üstün çocuklar lehine anlamlı farkın olduğu görülmüş, fakat diğer gruplar arasında anlamlı bir fark bulunmamıştır (Güven, 2001).

\subsection{Verilerin Toplanması}

Ölçme aracının İstanbul ili genelinde resmi ve özel, okul öncesi eğitim kurumlarına devam eden çocuklara uygulanması amacıyla İstanbul İl Milli Eğitim Müdürlüğü’ne başvurulmuş ve ölçeğin uygulama izni alınmıştır. Sonrasında belirlenen okullarda Kişisel Bilgi Formu ailelere ulaştırılmış ve veli izinleri alınıp Sezgisel Matematik Yeteneği Test'i çalışma grubunu oluşturan okullarda uygulanmıştır. Kişisel Bilgi Formları bazı okullara bilgisayar üzerinden ileti olarak gönderilmiş, bazı okullara elden teslim edilmiş ve okullar tarafından velilere ulaştırılıp toplanmıştır.

\section{Bulgular}

Araştırmanın amaçlarına yönelik olarak elde edilen bulgulara aşağıda yer verilmiştir. MEB programına ve Montessori yaklaşımına göre eğitim alan çalışma grubunu oluşturan çocukların sezgisel matematik yeteneklerinde cinsiyetlerine, okul öncesi eğitime devam etme sürelerine, anne ve baba öğrenim durumlarına göre anlamlı bir fark olup olmamasına ilişkin bulgular aşağıda verilmiştir. Verilerinin analizi öncesinde yapılan Kolmognov Smirnov testi verilerin normal dağıldığını ( $>$ >.05) göstermiştir.

Tablo 1: Çocukların Cinsiyetlerine Göre Anlamlı Bir Farklılık Olup Olmadığını Gösteren Bağımsız Gruplar T Testi Sonuçları

\begin{tabular}{lllllll}
\hline & Cinsiyet & N & Ort. & Std. Sap. & t & p \\
\hline \multirow{2}{*}{ MEB } & Kiz & 29 & 56,79 & 3,629 & & \\
\hline \multirow{2}{*}{ Montessori } & Erkek & 32 & 54,03 & 3,115 & 3,197 &, $002 *$ \\
& Kiz & 27 & 60,81 & 2,987 & & \\
& Erkek & 33 & 61,45 & 3,103 &,- 808 &, 423 \\
\hline
\end{tabular}

$\mathbf{1 7 0} \mid \mathrm{P}$ a g e 
Görüldüğü üzere MEB programına göre eğitim gören çocukların sezgisel matematik yeteneklerinde kız çocuklarının lehine anlamlı bir farklılık olduğu $(\mathrm{t}=3,197, \mathrm{p}<.05)$, Montessori yaklaşımına göre eğitim alan çocukların sezgisel matematik yeteneklerinde ise cinsiyetlerine yönelik anlamlı bir farklılık olmadı̆̆ görülmüştür $(\mathrm{p}>.05)$.

Tablo 2: Çocukların Okul Öncesi Eğitim Alma Sürelerine Göre Anlamlı Bir Farklılık Olup Olmadığını Gösteren Bağımsız Gruplar T Testi Sonuçları

\begin{tabular}{lllllll}
\hline & Eğitim Süresi & $\mathbf{N}$ & Ort. & Std. Sap. & t & p \\
\hline \multirow{2}{*}{ MEB } & 1 Yil & 50 & 55,08 & 3,568 & & \\
\hline \multirow{2}{*}{ Montessori } & 2 Yil ve üzeri & 11 & 56,54 & 3,778 & $-1,221$ &, 227 \\
& 1 Yil & 6 & 59,00 & 4,335 & & \\
& 2 Yil ve üzeri & 54 & 61,41 & 2,818 & $-1,877$ &, 066 \\
\hline
\end{tabular}

Tablo 2'de görüldüğü üzere MEB programına ve Montessori yaklaşımına göre eğitim alan çocukların sezgisel matematik yeteneklerinde okul öncesi eğitime devam etme sürelerine göre anlamlı bir farklılık görülmemiştir ( $>$ >.05).

Tablo 3: Çocukların Annelerinin Öğrenim Durumuna Göre Anlamlı Bir Farklılık Olup Olmadığını Gösteren ANOVA Sonuçları

\begin{tabular}{|c|c|c|c|c|c|}
\hline \multirow{5}{*}{ MEB } & & $\mathbf{N}$ & Ort. & $\mathbf{F}$ & p \\
\hline & Ortaokul ve altı & 37 & 54,86 & \multirow{4}{*}{,822 } & \multirow{4}{*}{,445 } \\
\hline & Lise veya Önlisans mezunları & 20 & 56,10 & & \\
\hline & Lisans veya Lisansüstü mezunları & 4 & 56 & & \\
\hline & Toplam & 61 & 55,34 & & \\
\hline \multirow{4}{*}{ Montessori } & Ortaokul ve altı & 4 & 60,75 & \multirow{4}{*}{,236 } & \multirow{4}{*}{,790 } \\
\hline & Lise veya Önlisans mezunları & 17 & 61,59 & & \\
\hline & Lisans veya Lisansüstü mezunları & 39 & 61,03 & & \\
\hline & Toplam & 60 & 61,17 & & \\
\hline
\end{tabular}

Bulgular MEB programına ve Montessori yaklaşımına göre eğitim alan çocukların sezgisel matematik yeteneklerinde anne öğrenim durumuna göre anlamlı bir farklılık olmadığını göstermiştir (p>.05). 
Tablo 4: Çocukların Babalarının Öğrenim Durumuna Göre Anlamlı Bir Farklılık Olup Olmadığını Gösteren ANOVA Sonuçları

\begin{tabular}{llllll}
\hline \multirow{3}{*}{ MEB } & & $\mathbf{N}$ & Ort. & F & p \\
\cline { 3 - 6 } & Ortaokul ve alt1 & 36 & 55,25 & & \\
& Lise veya Önlisans mezunları & 19 & 55,68 & \multirow{2}{*}{, 151} &, 860 \\
& Lisans veya Lisansüstü mezunları & 6 & 54,83 & & \\
& Toplam & 61 & 55,34 & & \\
\hline \multirow{2}{*}{ Montessori } & Ortaokul ve altı & 5 & 61,80 & & \\
& Lise veya Önlisans mezunları & 14 & 60,78 & \multirow{2}{*}{, 281} &, 805 \\
& Lisans veya Lisansüstü mezunları & 41 & 61,22 & & \\
& Toplam & 60 & 61,17 & & \\
\hline
\end{tabular}

Tablo 4'te görüldüğü üzere MEB programına ve Montessori yaklaşımına göre eğitim alan çocukların sezgisel matematik yeteneklerinde baba öğrenim durumuna göre anlamlı bir farklılık görülmemiştir ( $p>.05)$. Araştırmanın temel amacı MEB programına ve Montessori yaklaşımına göre eğitim alan çocukların sezgisel matematik yetenekleri arasında anlamlı bir farkın olup olmadığının araştırılması olarak belirtilmişti. Bu amaç doğrultusunda yapılan istatistik analiz sonucu Tablo 5'te verilmiştir.

Tablo 5: MEB Programı ve Montessori Yaklaşımına Göre Eğitim Alan Çocukların Sezgisel Matematik Yetenekleri Arasında Anlamlı Bir Fark Olup Olmadığını Gösteren Bağımsız Gruplar T Testi Sonuçları

\begin{tabular}{lccccc}
\hline Okul Türü & $\mathbf{N}$ & Ort. & Std. Sap. & t & $\mathbf{p}$ \\
\hline MEB & 61 & 55,34 & 3,619 & 9,571 &, $000^{*}$ \\
Montessori & 60 & 61,17 & 3,043 & & \\
\hline
\end{tabular}

Tablo 5 incelendiğinde; MEB programına ve Montessori yaklaşımına göre eğitim alan çocukların sezgisel matematik yetenekleri arasında Montessori yaklaşımına göre eğitim alan çocuklar lehine anlamlı bir farklılık olduğunu görülmüştür $(\mathrm{t}=9,571, \mathrm{p}<.05)$.

\section{Sonuç, Tartışma ve Öneriler}

\subsection{Sonuç ve Tartışma}

$\mathrm{Bu}$ bölümde araştırma sonucunda elde edilen bulgular tartışılmıştır.

MEB Okul Öncesi Eğitim Programı'na göre eğitim alan çocukların sezgisel matematik yeteneklerinde kız çocuklarının lehine anlamlı bir farklılık görülürken, Montessori yaklaşımına göre eğitim alan çocukların sezgisel matematik yeteneklerinde cinsiyetlerine yönelik anlamlı bir farklılık görülmemiştir. Alan yazın incelendiğinde erken çocuklukta matematik becerilerinin cinsiyete göre farklılık göstermediği çalışmalara daha sık rastlanmaktadır (Arnas, Gül \& Sığırtmaç, 2003; Bakker, Torbeyns, Wijns, Verschaffel \& De Smedt, 2018; Clements, 1999; Güven,1997; Güven, 2007; Güven, 2001; Karakuş \& Akman, 2015; Klein, 2010; Taşkın, 2013). Bunun yanında matematik becerilerinin okul öncesi dönem erkek çocukların lehine anlamlı farklılık gösterdiği çalışmalara da rastlanmıştır (Miller \& Bizzell, 1984; Robinson, 1996). Araştırmanın sonucuna bakıldığında, MEB programına göre eğitim alan kız çocukların sezgisel matematik yeteneklerinin erkek çocuklardan daha yüksek çıkması çalışma grubundan kaynaklanabilir.

MEB Programı'na ve Montessori yaklaşımına göre eğitim alan çocukların sezgisel matematik yeteneklerinde okul öncesi eğitime devam etme sürelerine göre anlamlı bir farklılık bulunmamıştır. Alan yazın incelendiğinde okul öncesine devam etme süresi arttıkça matematik yeteneğinin arttığ sonucuna ulaşan çalışmalara rastlanmıştır (Cinkılıç, 2009; Dağl1; 2007; Ergün, 2003; Güven, 2007; Karakuş \& Akman, 2015; Özdemir, 2018; Unutkan, 2007; Üstün \& Akman, 2003). Yapılan bu araştırmanın sonucu bu durumla

172|P a g e

wWw.iiste.org 
örtüşmemektedir. Alan yazın incelendiğinde araştırmanın bulgusunu destekleyen bir araştırmaya rastlanmamıştır. Bu bulgunun da sınırlı sayıda olan çalışma gruplarından kaynaklandığı düşünülmektedir. MEB programına ve Montessori yaklaşımına göre eğitim alan çocukların sezgisel matematik yeteneklerinde annenin ve babanın öğrenim düzeyine göre anlamlı bir farklılıklar görülmemiştir. Araştırmalar genelde anne öğrenim düzeyinin artmasının çocukların matematik yeteneklerini olumlu yönde etkilediğini göstermektedir (Dursun \& Dede, 2004; Güven, 1998; Güven, 2007). Araştırmadan elde edilen bulgu çalışma grubundan kaynaklanabilir. Ayrıca günümüzde eğitim düzeyi düşük olsa da teknolojiden doğru bir şekilde yararlanan ve çocuğuyla kaliteli vakit geçirmek için çabalayan bilinçli annelerin olması ve bazı çalışan ve öğrenim düzeyi yüksek annelerin de çocuklarıyla yeterince vakit geçiremiyor olması bu sonucun ortaya çıkmasına neden olmuş olabilir. Diğer taraftan alan yazın incelendiğinde genelde bulgular baba öğrenim düzeyinin artmasının çocukların matematik yeteneklerini olumlu yönde etkilediğini göstermektedir (Dursun \& Dede, 2004; Güven, 1998; Güven, 2007; Özdemir, 2018). Araştırmanın sonucuna göre babanın öğrenim durumunun çocukların sezgisel matematik yetenekleri üzerinde anlamlı bir farklılık yaratmaması toplumsal yapımız itibariyle beklenen bir durum olabilir. İçinde bulunduğumuz toplumda çocuğu büyütme ve çocukla ilgilenme işi genellikle annenin görevi olduğundan, babaların öğrenim durumlarının çocukların sezgisel matematik yetenekleri üzerinde fark yaratmadığ 1 sonucuna ulaşılabilir.

Araştırmanın temel amacı MEB programına göre eğitim alan çocuklar ile Montessori yaklaşımına göre eğitim alan çocuklar arasında sezgisel matematik yetenekleri açısından anlamlı bir fark olup olmadığını incelemektir. Bu çalışmanın bulguları Montessori yaklaşımına göre eğitim alan çocuklar lehine anlamlı bir farklılık olduğunu göstermiştir. Ülkemizde yapılan çalışmalar incelendiğinde Montessori yaklaşımının çocukların matematik yeteneği ve matematiksel kavramları öğrenmeleri üzerinde MEB programına göre daha etkili olduğunu gösteren çalışmalara rastlanmıştır (Aydoğan Akuysal, 2007; Kırlar, 2006; Öngören, 2008; Toran, 2011; Yiğit, 2008). Yurtdışında yapılan çalışmalarda, ülkelerin mevcut ulusal programları ile Montessori yaklaşımının matematik yeteneği veya matematik kavram kazanımları üzerindeki etkisine bakıldığında; Montessori yaklaşımının lehine sonuçlanan araştırmalara da rastlanmaktadır (Dohrmann, 2003; Ervin, 2010; Faryadi, 2017; Fitzpatrick vd., 2014; Gross, 1970; Harris, 2007; Hobbs 2008; Lillard \& ElseQuest, 2006; Lillard \& Heise, 2016; McIntosh, 2015; Peng \& Md-Yunus, 2014; Toran \& Temel, 2014; Yiğit, 2008; White, Yussen \& Docherty, 1976). Bunların yanında ulusal programlar ve Montessori yaklaşımı arasında matematik yeteneği açısından fark bulunmayan araştırmalar da mevcuttur (Laski, Vasilyeva, Schiffman \& Ermakova, 2016; Lopata, Wallace, \& Finn, 2005; Mallett \& Schroeder, 2015; Miller \& Bizzell, 1984).

Araştırmanın sonucuna göre Montessori yaklaşımının okul öncesi dönem çocuklarının sezgisel matematik yeteneklerini pozitif etkilediği söylenebilir. $\mathrm{Bu}$ durum; Montessori eğitim ortamının çocuğun kendi çalışmasını seçmeye ve yapmaya firsat veren bir yapıda olmasından ve materyallerin yapılandırılmış olması özelliklerinden kaynaklanabilir. Diğer taraftan her iki program çocuk merkezli olsa ve bireysellik ilkesine önem verse de Montessorri okullarında çocuk bu şansı daha çok yakalamaktadır. Çünkü ulusal programın uygulandığı sınıflarda öğretmenlerin her çocuğun bireysel özelliklerine göre eğitim vermesi ve yaparakyaşayarak öğrenmelerinde çocuklara fırsat tanıması, fırsatlar için zaman ayırabilmesi yeterli düzeyde olmayabilir. Oysa çocuklar materyallerle ne kadar çok oynar ve kendi düzeylerine uygun eğitim fırsatı yakalarlarsa sezgisel düşünmeyi geliştirecek deneyimleri de o derece artacaktır. Ayrıca Montessori sınıflarında çocuğun doğa ile ve gerçek nesnelerle daha çok teması söz konusudur. Bu da çocuklara sezgilerinin doğru veya yanlış olduğunu test etme şansı tanımaktadır.

\section{2. Öneriler}

Araştırmanın sonuçları göz önüne alınarak uygulayıcılara ve araştırmacılara bazı öneriler sunulabilir. Örneğin; okul öncesi öğretmenlerinin günlük planları içerisinde çocukların sezgisel matematik yeteneklerini geliştirecek etkinliklere daha çok yer vermeleri önerilebilir. Okul öncesi dönem çocuklara matematik kavramları kazandırılırken Montessori yaklaşımının matematik materyallerinin temel özellikleri MEB programları için uyarlamalar yapılabilir. Yapılan araştırmanın sınırlı bir çalışma grubuna sahip olması nedeniyle bu konuyla ilişkili başka çalışmalarda daha büyük bir çalışma grubu ile çalışılabilir ve çocukların sezgisel matematik yetenekleri daha farklı eğitim yaklaşımlarına göre (High Scope, Reggio Emilia gibi) eğitim alan çocuklar açısından da karşılaştırılabilir. 
International Journal of Scientific and Technological Research

ISSN 2422-8702 (Online), DOI: 10.7176/JSTR/6-06-12

Special Issue of Educational Sciences, Vol.6, No.6, 2020

\section{Kaynakça}

Arnas, Y. A., Gül, E. D., \& Sığırtmaç, A. (2003). 48-66 ay çocuklar için sayı ve işlem kavramları testi'nin geçerlilik ve güvenilirlik çalışması. Çukurova Üniversitesi Sosyal Bilimler Dergisi, 12(12), 147-153.

Avci, K. (2015). Okul öncesi eğitimi alan 48-66 aylık çocukların matematik becerilerinin bazı değişkenler açısından incelenmesi. Yayınlanmamış Yüksek Lisans Tezi. On Sekiz Mart Üniversitesi, Çanakkale.

Aydın, İ. (2015). Alternatif Okullar. Ankara: Pegem Akademi.

Aydoğan Akuysal, S. (2007). 6 yaş çocuklarının geometrik şekil ve sayı kavramlarının gelişiminde kavram eğitim programının etkisi. Yayınlanmamış Yüksek Lisans Tezi. Adnan Menderes Üniversitesi, Aydin.

Bağc1, B., \& İvrendi, A. (2016). Türkiye' de okul öncesi dönem matematik becerileri ve eğitimi araştırmaları: Sentez çalışması. Necatibey Eğitim Fakültesi Elektronik Fen ve Matematik Eğitimi Dergisi, 10(2), 391-425.

Bakker, M., Torbeyns, J., Wijns, N., Verschaffel, L., \& Smedt, B. D. (2018). Gender equality in 4- to 5year-old preschoolers' early numerical competencies. Developmental Science, 22, 1-7. doi:10.1111/desc. 12718

Bruner, J. S. (1983). Intuitive and Analytic Thinking. M. Donaldson, R. Grieve, \& C. Pratt (Eds) içinde, Early Childhood Development and Education: Readings in Psychology. Oxford: Basil Blackwell.

Canoğlu, M. (2007). Okul öncesi eğitim kurumlarına devam eden 6 yaş grubu çocuklarda proje tabanlı öğrenmenin sezgisel matematik becerilerine etkisi. Yayınlanmamış Yüksek Lisans Tezi. Abant İzzet Baysal Üniversitesi, Bolu.

Ceylan, M. (2016). Okul öncesi dönemde erken matematik yeteneği düzeyleri. Yayınlanmamış Yüksek Lisans Tezi. Dokuz Eylül Üniversitesi, İzmir.

Cinkılıç, H. (2009). Okul öncesi eğitimin ilköğretim 1. sınıf öğrencilerinin okul olgunluğuna etkisinin incelenmesi. Yayınlanmamış Yüksek Lisans Tezi. Selçuk Üniversitesi, Konya.

Clements, D. H., Swaminathan, S., Hannibal, M. Z., \& Sarama, J. (1999). Young children's concepts of shape. Journal for Research in Mathematics Education, 30(2), 192-212.

Cossentino, J. (2006). Big work: goodness, vocation, and engagement in the Montessori Method. Curriculum Inquiry, 36(1), 63-92.

Çakıroğlu Wilbrandt, E. (2017). Maria Montessori Yöntemiyle Çocuk Eğitimi Sanatı Eğitimciler ve Ebeveynler Için El Kitabı. İstanbul: Aura.

Çelik, M., \& Kandır, A. (2011). Matematik gelişimi 6 testi (Progress in Maths) nin 60-77 aylar arasında olan çocuklar için geçerlik ve güvenirlik çalışması. Kuramsal Eğitimbilim, 4(1), 146-153.

Dağlı, A. (2007). Okul öncesi eğitim alan ve almayan ilköğretim birinci sınıf öğrencilerinin Türkçe ve matematik derslerindeki akademik başarılarının karşılaştırılması. Yayınlanmamış Yüksek Lisans Tezi. Selçuk Üniversitesi, Konya.

Dixon, J. A., \& Moore, C. F. (1996). The developmental role of intuitive principles in choosing mathematical strategies. Developmental Psychology, 32(2), 241-253. 
International Journal of Scientific and Technological Research

ISSN 2422-8702 (Online), DOI: 10.7176/JSTR/6-06-12

Special Issue of Educational Sciences, Vol.6, No.6, 2020

Dohrmann, K. R. (2003). Outcomes for students in a Montessori program: A longitudinal study of the experience in the Milwaukee Public Schools, Association Montessori International of United States of America (AMI-USA).

Durakoğlu, A. (2010). Maria Montessori'ye göre çocuğun doğası ve eğitimi. Doktora Tezi. Gazi Üniversitesi, Ankara.

Dursun, Ş., \& Dede, Y. (2014). Öğrencilerin matematikte başarısını etkileyen faktörler: matematik öğretmenlerinin görüşleri bakımından. Gazi Eğitim Fakültesi Dergisi, 24(2), 223.

Erdoğan, S. (2006). Altı yaş grubu çocuklarına drama yöntemi ile verilen matematik eğitimin matematik yeteneğine etkisinin incelenmesi. Doktora Tezi. Ankara Üniversitesi.

Ervin, B., Wash, P. D., \& Mecca, M. E. (2010). A 3-year study of self-regulation in Montessori and NonMontessori classrooms. Montessori Life, 22(2), 22-31.

Faryadi, Q. (2017). The application of Montessori method in learning mathematics: an experimental research. Open Access Library Journal, (4).

Fitzpatrick, C., McKinnon, R. D., Blair, C. B., \& Willoughby, M. T. (2014). Do preschool executive function skills explain the school readiness gap between advantaged and disadvantaged children? Learning and Instruction,(30), 25-31.

Gross, R., Green, B., \& Clapp, D. (1970). The Sands School Project: Thirthy Year Results. Cincinnati University, Ohio.

Güven, Y. (1997). Erken Matematik Yeteneği Testi-2'nin geçerlik, güvenirlik, norm çalışması ve sosyokültürel faktörlerin matematik yeteneğine etkisinin incelenmesi. Doktora Tezi. Marmara Üniversitesi, İstanbul.

Güven, Y. (1998). Kız ve erkek çocuklarda matematik yeteneği ve matematik başarısı konusunda okulöncesi ve ilkokul (ilköğretim) öğretmenlerinin görüşlerinin değerlendirilmesi. M. Ü. Atatürk Ĕ̌itim Fakültesi Ĕ̆itim Bilimleri Dergisi, (10), 121-138.

Güven, Y. (2001). Sezgisel Matematik Yeteneği Testi'nin geliştirilmesi. Türk Psikolojik Danışma ve Rehberlik Dergisi, 23-28.

Güven, Y. (2004). Aile ve öğretmen katılım programlarının 5 yaş grubu çocukların matematiksel szegilerine etkisi. Marmara Üniversitesi Atatürk Eğitim Fakültesi Eğitim Bilimleri Dergisi, (19), 8594.

Güven, Y. (2005). Erken Çocuklukta Matematiksel Düşünme ve Matematiği Öğrenme. İstanbul: Küçük Adımlar Eğitim Yayınları.

Güven, Y. (2007). Okulöncesi dönem çocuklarının sezgisel matematik yeteneklerinin incelenmesi. Marmara Üniversitesi Sosyal Bilimler Enstitüsü Dergisi, 7(28), 387-395.

Harris, M. A. (2007). Differences in mathematics scores between students who receive traditional montessori instruction and students who receive music enriched Montessori instruction. Journal for Learning Through the Art, 3(1).

Hobbs, A. (2008). Academic achievement: Montessori and Non-Montessori private school settings. Unpublished Doctoral Dissertation. University of Houston, Houston.

Jordan, N., Kaplan, D., Ramineni, C., \& Locuniak, M. (2009). Early math matters: kindergarten number competence and later mathematics outcomes. Developmental Psychology, 45(3), 850.

$\mathbf{1 7 5} \mid \mathrm{P}$ a g e

www.iiste.org 
International Journal of Scientific and Technological Research

ISSN 2422-8702 (Online), DOI: 10.7176/JSTR/6-06-12

Special Issue of Educational Sciences, Vol.6, No.6, 2020

Karakuş, H., \& Akman, B. (2015). Okul öncesi dönem çocuklarının matematik kavram kazanımlarının incelenmesi. Ĕgitim Bilimlerinde Yenilik ve Nitelik Arayışı, 476-488.

Karasar, N. (2016). Bilimsel Araştırma Yöntemi. Ankara: Nobel.

Keçecioğlu, Ö. (2015). MEB okul öncesi eğitim programı ve montessori yaklaşımına göre eğitim alan 5 yaş çocuklarının sosyal becerilerinin incelenmesi. Yayınlanmamış Yüksek Lisans Tezi. Marmara Üniversitesi, İstanbul.

Kırlar, B. (2006). Okulöncesi eğitim kurumlarına devam eden altı yaş çocuklarına bazı matematiksel kavramları kazandırmada yapılandırılmış yöntem ile geleneksel yöntemin etkililiğinin karsılaştırmalı olarak incelenmesi. Yayınlanmamış Yüksek Lisans Tezi. Selçuk Üniversitesi, Konya.

Klein, P. S., Adi-Japha, E., \& Hakak-Benizri, S. (2010). Mathematical thinking of kindergarten boys and girls: Similar achievement, different contributing processes. Educational Studies in Mathematics, 73(3), 233-246.

Korkmaz, H. E. (2005). Montessori Metodu ve Montessori okulları: Türkiye`de Montessori okullarının yönetim ve finansman bakımından inclenmesi. Yayınlanmamış Yüksek Lisans Tezi. Marmara Üniversitesi, İstanbul.

Köksal Aksoy, A., \& Aslan, D. (2006). Okulöncesi eğitimde proje yaklaşımı. Mesleki Eğitim Dergisi, $8(16), 87-105$.

Küçükkaragöz, H. (2011). Bilişsel Gelişim ve Dil Gelişimi. B. Yeşilyaprak içinde, Eğitim Psikolojisi Gelişim-Öğrenme-Öğretim (s. 97). Ankara: Pegem Akademi.

Laski, E. V., Schiffman , J., Vasilyeva, M., \& Ermakova, A. (2016). Arithmetic accuracy in children from high- and low-income schools: What do strategies have to do with it? AERA Open, 2(2), 1-14.

Lillard, A. S., \& Else-Quest, N. (2006). The early years: Evaluating Montessori. Science, 313(5795), 1893-1894.

Lillard, A. S., \& Heise, M. J. (2016). Removing supplementary materials from Montessori classrooms changed child outcomes. Journal of Montessori Research, 12(1).

Lopata, C., Wallace, N., \& Finn, K. (2005). Comparison of academic achievement between Montessori and traditional education programs. Journal of Research in Childhood Education, 20(1), 5-13.

Lopez, E. M., Gallimore, R., Garnier, R., \& Reese, L. (2007). Preschool antecedents of mathematics achievement of latinos the influence of family resources, early literacy experiences, and preschool attendance. Hispanic Journal of Behavioral Sciences, 29(4), 456-471.

Mallett, J. D., \& Schroeder, J. L. (2015). Academic achievement outcomes: A comparison of Montessori and non-Montessori public elementary school students. Journal of Elementary Education, 25(1), 3953.

Mazzocco, M. M., \& Thompson, R. E. (2005). Kindergarten predictors of math learning disability. Learning Disabilities Research \& Practice, 20(3), 142-155.

McIntosh, K. L. (2015). Montessori Mathematics curriculum and lower elementary students understanding of length measurement. Masters of Arts in Education Action Research Papers. St. Catherine University, Sophia.

MEB. (2013). Milli Ĕgitim Bakanlığı Okul Öncesi Ĕgitim Programı. Ankara.

176|P a g e

www.iiste.org 
International Journal of Scientific and Technological Research

ISSN 2422-8702 (Online), DOI: 10.7176/JSTR/6-06-12

Special Issue of Educational Sciences, Vol.6, No.6, 2020

Miller, L. B., \& Bizzell, R. P. (1984). Long-term effects of four preschool program: ninth-and tenthgrade results. Child Development, (55), 1570-1587.

Montessori, M. (1936/1997). Çocuk Ĕgitimi (Montessori Metodu) (5. Basım b.). (G. Yücel, Çev.) İstanbul: Özgür Yayınları.

Oğuz, V., \& Köksal Akyol, A. (2006). Çocuk eğitiminde Montessori yaklaşımı. Çukurova Üniversitesi Sosyal Bilimler Enstitüsü Dergisi, 15(1), 243-256.

Oktay, A. (1987). Okulöncesi eğitimde çağdaş bir yaklaşım: Montessori yöntemi. Ya-Pa, 5. Okulöncesi Eğitimi ve Yaygınlaş̧tırma Semineri, (s. 62-69). Antalya.

Öngören, S. (2008). Okulöncesi eğitim kurumlarına devam eden 4-5 yaş grubu çocuklarına geometrik şekil kavramı kazandırmada Montessori eğitim yönteminin etkililiği. Yayınlanmamış Yüksek Lisans Tezi. Selçuk Üniversitesi, Konya.

Özdemir, A. F. (2018). Okul öncesi eğitimi alan 66-72 aylık çocukların baba katılımı ile erken dönem matematik becerileri arasındaki ilişkinin incelenmesi. Yayınlanmamış Yüksek Lisans Tezi. Maltepe Üniversitesi, İstanbul.

Peng, H.-H., \& Md-Yunus, S. (2014). Do children in Montessori schools perform better in the achievement test? A Taiwanese perspective. International Journal of Early Childhood, 46(2), 299311.

Polat Unutkan, Ö. (2007). Okul öncesi dönem çocuklarının matematik becerileri açısından ilköğretime hazır bulunuşluğunun incelenmesi. Hacettepe Üniversitesi Eğitim Bilimleri Dergisi, (32), 243-254.

Robinson, N. M., Abbott, R. D., Berninger, V. W., \& Busse, J. (1996). Structure of abilities in mathprecocious young children: Gender similarities and differences. Journal of Educational Psychology, $88(2), 341$.

Sobe, N. (2004). Challenging the gaze: the subject of attention and a 1915 Montessori demonstration classroom. Educational Theory, 54(3), 281-297.

Taşkın, N. (2013). Okul öncesi dönemde matematik ve dil arasındaki ilişsi üzerine bir inceleme. Doktora Tezi. Hacettepe Üniversitesi, Ankara.

Temel, F., \& Toran, M. (2013). Erken Çocukluk Eğitiminde Yaklaşımlar ve Programlar (2. b.). Ankara: Vize Basın Yayın.

Topbaş, E. (2017). Montessori Yöntemi ile Çocuk Eğitimi. Ankara: Panama Yayıncılık.

Toran, M. (2015). Steiner Pedagojisi ve Waldorf Okulları. Z. F. Temel içinde, Okul öncesi Eğitimde Alternatif Yaklaşımlar. Ankara: Hedef Yayıncılık.

Toran, M. (2011). Montessori yönteminin çocukların kavram edinimi, sosyal uyumları ve küçük kas motor becerileri üzerindeki etkisinin incelenmesi. Doktora Tezi. Gazi Üniversitesi, Ankara.

Toran, M., \& Temel, Z. F. (2014). Montessori yaklaşımın çocukların kavram edinimi üzerindeki etkisinin incelenmesi. Elementary Education Online, 13(1), 223-234.

Üstün, E., \& Akman, B. (2003). Üç yaş grubu çocuklarda kavram gelişimi. Hacettepe Üniversitesi Eğitim Fakültesi Dergisi, (24), 137-141. 
International Journal of Scientific and Technological Research

ISSN 2422-8702 (Online), DOI: 10.7176/JSTR/6-06-12

Special Issue of Educational Sciences, Vol.6, No.6, 2020

White, J. M., Yussen, S. R., \& Docherty, E. M. (1976). Performance of Montessori and traditionallyn schooled nursery children on tasks of seriation, classification and conservation. Contemporary Educational Psychology, (1), 356-368.

Yiğit , T. (2008). Okulöncesi eğitim kurumlarında montessori ve geleneksel öğretim yöntemleri alan çocukların sayı kavramı kazanma davranışlarının karşılaştırılması. Yayınlanmamış Yüksek Lisans Tezi. Selçuk Üniversitesi, Konya.

Yıldız, F. Ü. (2018). Montessori anne destek eğitim programının; Montessori eğitimi alan 4-5 yaş çocukların matamatik ve günlük yaşam becerilerine etkilerinin incelenmesi. Doktora Tezi. Selçuk Üniversitesi Sosyal Bilimler Enstitüsü, Konya. 